However, the proposal has generated some controversy among faculty members over how compatible a virtually autonomous research institute would be with traditional academic practices. And the MIT debate is being watched closely by other research universities .

In the case of the Whitehead Institute, the debate has focused on the implications of the "dual allegiance" of the research staff. These will have joint appointments between the institute and MIT, and although the staff will be appointed and paid by the Whitehead Institute, MIT's own research and review procedures for recruitment would apply.

However, at a faculty meeting last month, several members asked whether academic staff paid for entirely by outside funds would participate fully in activities not directly related to their research, such as undergraduate teaching or participation on administrative committees.

Responding to some of these concerns, the Whitehead Institute has agreed that three MIT representatives should be appointed to its board of trustees - these are former president Jerome B. Wiesner, dean Abraham Siegel of the MIT Management School and Dr W. Gerald Austen, chief of surgical services at the Massachusetts General Hospital. Other trustees include Dr Donald Fredrickson, past director of the National Institutes of Health, and three members of the Whitehead family.

In a letter sent to faculty members before the September meeting, Dr Low said that he and president Paul Gray had concluded that the benefits of the proposed arrangement for MIT seem to outweigh the potential problems.

At the faculty meeting itself, Dr Baltimore answered critics of the proposal by saying that he intended to make sure that staff members of the Whitehead Institute fully participated in activities apart from teaching.

In reply to a question about the decision by Duke University in North Carolina to turn down a similar offer from $\mathrm{Mr}$ Whitehead to fund an independent research institute seven years ago, Dr Low said that at the time Mr Whitehead's ideas had been more medically oriented. Having discussed the Duke decision with its president, Mr Terry Sanford, he said that he was convinced that there was nothing in the decision to deter a possible MIT affiliation.

The MIT Corporation, which is formally responsible for the affairs of MIT, will discuss Mr Whitehead's of fer at its meeting tomorrow. Any conclusions reached or recommendations made at today's faculty meeting will be passed on to the corporation, although a spokesman for MIT said last week that he does not anticipate any substantial opposition.

It is intended that the Whitehead Institute should be independent of commercial interests. Although, like MIT, it will have patent rights to the results of its own research, no company will have preferential right to the licences. A final decision is expected at the corporation's meeting in December.

David Dickson

\section{UK industry fights genetic guidelines}

British industry is unlikely to be satisfied by the relaxation of guidelines for the industrial application of genetic manipulation which the Genetic Manipulation Advisory Group (GMAG) plans to approve this week. The new guidelines have been through several drafts since they were first discussed earlier this year. The latest draft removes the present obligation on industry to give warning when it plans to use cultures of more than 10 litres when laboratory-scale experiments with the microorganisms are exempt from notification. Instead, companies would be required to notify the group only at the start of their operations. But notification of large-scale operations with organisms classified for laboratory purposes in category 1 or above would still have to be given well in advance.

The spur for revising the guidelines came earlier in the year, when the Confederation of British Industry (CBI) produced its own recommendations. In particular, it urged that processes using microorganisms exempt from regulation at the laboratory level should be exempt from notification, and that notification alone should be sufficient for large-scale operations with category 1 micro- organisms. In all cases, the confederation argued, the same basis should be used for the assessment of large-scale and laboratory manipulation, but GMAG does not agree.

CBI's proposals echo its longstanding discontent with GMAG as such. Thus the confederation has urged that processes using microorganisms in higher categories of containment should be controlled by the newly reconstituted Advisory Committee on Dangerous Pathogens, on the grounds that too many regulatory bodies are involved, but also on the grounds of confidentiality. It also suggests that GMAG should transfer its responsibilities to the Health and Safety Executive, which should recruit its own staff inspectors and, when necessary, take advice from the Dangerous Pathogens Committee.

CBI's recommendations would effectively rob GMAG of control of industrial processes. GMAG's members, however, believe that the group should at least be aware of all new activities. The likely outcome is that GMAG's draft guidelines will be approved but that the dissenting voice of CBI will ensure that the debate continues. Judy Redfearn

\section{European space industry}

\section{Landing platform}

The European Parliament is urging the community of ten to formulate a long-term strategy for developing Europe's fledgling space industry. Last week, members of the parliament adopted a resolution calling for the speedy development of new space technologies that could enable Europe to compete with the United States space shuttle. In a vote that broadly endorsed the recommendations of a working document prepared by $\mathbf{M}$. André Turcat, a French member of the parliament and an exConcorde test pilot, they also called for a conference of European space ministers at the earliest opportunity.

The parliament's initiative is slightly unusual. Space policy has been largely left to those nations that have their own programmes and the members of the European Space Agency (ESA), not all of whom belong to the European Community. The initiative, however, comes at a time when the space agency is battling with the task of resolving national differences in drawing up a medium-term plan. The politicians are anxious that Europe should make a greater and more united effort.

M. Turcat argues in his document that the effort should be directed to competing in the growing world market for applications satellites and the vehicles to launch and even recover them. $\mathrm{He}$ estimates that the European space industry will grow to at least 10,000 million European units of account ( 1 EUA =

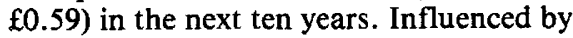
the recent decision of the National Aeronautics and Space Administration to cancel its contribution to the International SolarPolar Mission, he also argues for greater European independence.

That could be achieved, the document claims, if Europe were to develop technologies for establishing space stations and building unmanned, reusable vehicles capable of servicing them. Such a view will hearten members of the French national space agency, CNES, which is shortly to submit to ESA a proposal for a partly reusable launch vehicle. But enthusiasm from other quarters may be muted. Not all members of ESA are keen to devote the agency's limited budget to such a costly project.

The differences, however, may be resolved if, as the document argues, more money is devoted to space. That will be for the individual governments to decide. But one possibility, suggested in the debate on the document, is that the European Investment Bank should step in.

Such a major project would also involve some reorganization within the European space industry and possibly extending the role of ESA. While acknowledging that cooperation between Europe's diverse space industries has come a long way in the past six years, the document calls for even greater cohesion, suggesting collaboration 
along the lines of the successful aeronautics conglomerate, Airbus-Industrie. Government money should be available, not only for development within ESA but also to encourage industry.

The more immediate and less contentious goals, supported by the parliament, include an early decision to go ahead with Ariane 4-a modification of the current Ariane, whose fourth test flight is now scheduled for 14 December, that will launch heavier payloads - and the formulation by the European Commission of a feasibility study for a large space station.

If nothing else, last week's vote could result in a meeting of space ministers with the opportunity for thrashing out a realistic policy.

Judy Redfearn

\section{US-Soviet exchanges}

\section{Students to stop}

\section{Washington}

The US Congress, in a little-noticed manoeuvre, is trying to cut off all federal funds used to support Soviet students studying science and technology subjects in US universities under the official exchange programme between the two countries. The proposed ban would remain until restrictions are removed which prevent American students from learning about such subjects in the Soviet Union.

The move, which would be made through an amendment to the budget of the State Department and is said to have the department's support, would affect about 40 Soviet citizens who take university courses in the United States every year. It is part of a campaign by certain members of Congress to restrict Soviet access to American technology and expertise.

The amendment would prevent both the State Department and the International Communications Agency after 1 July 1982 from financing any long-term scientific or technological study in the United States by citizens of the Soviet Union in the USUSSR Graduate Student/Young Faculty Exchange, or in the USSR Senior Scholar Exchange.

Such exchanges are organized through the New York-based International Research and Exchanges Board (IREX), which this year has placed 31 Soviet scientists at US institutions including Massachusetts Institute of Technology, Stanford University and the University of California, Los Angeles.

Some officials responsible for the educational exchange programme have for some time complained that US students who visit the Soviet Union under the same programme are restricted to studying the arts, humanities and social sciences, and are not permitted to look at aspects of Soviet technology.

Introducing an amendment to the State Department authorization bill on the floor of the House of Representatives last week,
Mr Paul Findley, a Republican Representative from Illinois, described it as an attempt to ensure "the mutuality of any academic exchanges that may occur between the Soviet Union and the United States in the future"'.

The amendment was passed unanimously. And although the bill in its present form has been temporarily shelved to await further budget decisions by the Administration, a spokesman for $\mathrm{Mr}$ Findley said last week that the Senate had already indicated its support for the amendment, which he said was "almost certain" to become law when the State Department's budget was finally agreed.

Although scientific exchanges with the Soviet Union were substantially reduced by the Carter Administration in response to the occupation of Afghanistan, they are still continuing. At the National Academy of Sciences, for example, visits by US scientists to the Soviet Union arranged on an exchange basis with funds from the National Science Foundation have dropped from 100 to 60 a month.

The proposed congressional action would therefore only affect a part of the academic exchange programme between the two countries, although others may well fall victim to the budget cuts now under discussion in Congress.

Mr Alan Kassos, director of IREX, said last week that if the amendment passed into law it could cripple access by American students to the Soviet Union, IREX disputes Mr Findley's charges that visiting Soviet scientists are being given free access to US technology which could be of military or commercial value. The 31 currently studying in the US, for example, were all intensively screened by federal agencies such as the State Department, the Department of Defense and the Department of Commerce - a process which excluded a further 23 potential students on the grounds that their presence could violate export controls on scientific and technological data.

Replying to the charge that there is an imbalance in the subjects studied by US and USSR students, IREX points out that each side selects candidates whose proposed field of study is felt to meet national interests. "The US side chooses to send candidates in the humanities and social sciences because we feel it is imperative to know about the dynamics of Soviet society" said Mr Dan Matuszewski of IREX, adding that IREX had also occasionally organized visits by research workers in fields such as mathematics and plasma physics.

Officially the State Department still favours such academic exchanges as one window that was kept open when other bilateral exchange agreements were cut back after the occupation of Afghanistan. IREX still hopes that it will be possible to head off the Findley amendment when it comes up for debate again on the floor of the House.

David Dickson

\section{Attack on refusniks}

The Soviet authorities appear to be launching a concerted campaign to stop the various Jewish refusnik seminars from reconvening in this academic year. Especially heavy pressure has been applied to the oldest - the Moscow Sunday Seminar, founded in 1973, which, since the arrest of Viktor Brailovskii in November 1980, has been hosted by his wife Irina. Ten leading members of the group - including $\mathrm{Dr}$ Brailovskaya herself, and also $\mathrm{Dr}$ Aleksandr Ioffe and Dr Yakov Al'pert, have been threatened with official reprisals, ranging from expulsion from Moscow to imprisonment if the seminars continued, and all have been placed under overt police surveillance.

In the case of the Khar'kov engineering seminar, matters have proceeded further than threats. Its leader, Aleksandr Paritskii, recently deprived of his degree of Candidate of Science, was arrested early in September and now faces charges of slandering the Soviet Union. (This is, apparently, in connection with a letter which he and some forty other refusniks signed more than a year ago, asking the Communist Party to intervene with the passport authorities, so that they could leave for Israel.)

For Dr Aleksandr Lerner, however, the approach was somewhat different. Dr Lerner, who filed his application for emigration in 1971, has on occasion been informed that he would "never" be allowed to leave. Last month, however, he was given to understand that if he discontinued his cybernetics seminars, a visa might be forthcoming. Dr Lerner's case has attracted considerable attention abroad - indeed, a special "Lerner Circle" of fellow cyberneticists has been established - and this may account for the difference in attitude. In July, when Dr Lerner's wife died, the Soviet authorities granted an unprecedented visa to their daughter, Dr Sonya Lerner-Levine, now working at the Weizmann Institute in Israel, to return to Moscow for the funeral.

Support from foreign colleagues is also believed to have influenced the authorities in the case of Viktor Brailovskii who is now serving a sentence of five years' internal exile. Dr Brailovskii was convicted on 18 June, but was not transferred to his place of banishment until September. This was not, as had been feared, Siberia, but the village of Beineu in Kazakhstan, which has a far milder climate. And instead of being transferred from prison in a closed railway wagon, he was flown to Beineu. These were concessions made by the legal authorities on account of his weak state of health but Irina Brailovskaya believes they would not have been granted without international pressure.Vera Rich 